\title{
PENGARUH GAYA KOMUNIKASI ORGANISASI TERHADAP PRESTASI KERJA PEGAWAI PADA BIRO KOMUNIKASI LAYANAN MASYARAKAT KEMDIKBUD JAKARTA
}

\author{
Waluyo ${ }^{1}$ \\ Dosen Prodi Sekretari Universitas Pamulang \\ waluyop4tkbispar@gmail.com \\ Hermawan $^{2}$ \\ Mahasiswa Prodi Manajemen Universitas Pamulang \\ hermawan1112@gmail.com
}

\begin{abstract}
Abstrak - Tujuan penelitian adalah untuk mengetahui besarnya pengaruh penerapan pola komunikasi organisasi terhadap kinerja pegawai pada Biro Komunikasi Layanan Masyarakat Kemdikbud Jakarta. Sampel dalam penelitian ini sebanyak 50 orang karyawan dari 102 populasi. Metode pengumpulan data yang digunakan dalam penelitian ini adalah dengan menggunakan kuesioner dan diolah dengan analisis regresi sederhana. Uji instrumen penelitian dengan uji validitas dan uji reliabilitas. Uji hipotesis menggunakan uji t (parsial), dan analisis koefisien determinasi dengan bantuan software SPSS 21 for Windows. Dari hasil uji deskriptif menunjukkan bahwa responden yang memberikan penilaian terhadap indikator komunikasi dari atas kebawah dalam kategori tinggi yaitu sebanyak 8 orang (16\%), responden yang memberikan penilaian dalam kategori sedang yaitu sebanyak 35 orang (70\%), dan responden yang memberikan penilaian dalam kategori rendah yaitu sebanyak 7 orang (14\%). Responden yang memberikan penilaian terhadap variabel pola komunikasi dari bawah ke atas dalam kategori tinggi yaitu sebanyak 8 orang (16\%), responden yang memberikan penilaian terhadap variabel pola komunikasi dari bawah keatas dalam kategori sedang yaitu sebanyak 34 orang $(68 \%)$, dan responden yang memberikan penilaian dalam kategori rendah yaitu sebanyak 8 orang $(16 \%)$. Responden yang memberikan penilaian terhadap indikator variabel pola komunikasi horizontal dalam kategori tinggi yaitu sebanyak 8 orang $(16 \%)$, responden yang memberikan penilaian dalam kategori sedang yaitu sebanyak 35 orang $(70 \%)$, dan responden yang memberikan penilaian dalam kategori rendah yaitu sebanyak 7 orang (14\%). Pola komunikasi horizontal mayoritas dinilai dalam kategori sedang (70\%). Berdasarkan hasil uji koefisien maka penerapan pola komunikasi memberikan kontribusi pengaruh sebesar 48,9\% terhadap kinerja pegawai, sedangkan sisanya sebesar $100 \%-48,9 \%=51,1 \%$, disebabkan oleh variabel lainnya yang tidak diteliti. Berdasarkan hasil uji t diatas dapat diketahui variabel Pola Komunikasi (X) memiliki nilai thitung 6,779 > tabel 1,667. Hal ini berarti variabel pola komunikasi berpengaruh positif terhadap kinerja pegawai, dan diperoleh hasil signifikan yang menunjukkan nilai $0,000<0,05$ yang berarti terdapat pengaruh yang signifikan antara pola komunikasi dan kinerja pegawai. Hal ini menunjukan bahwa Ho ditolak dan Ha diterima, artinya variabel penerapan pola komunikasi berpengaruh positif terhadap kinerja pegawai pada Biro Komunikasi Layanan Masyarakat Kementerian Pendidikan dan Kebudayaan Jakarta. Sehingga, jika nilai pola komunikasi naik maka kinerja pegawai akan meningkat secara signifikan.
\end{abstract}

Kata kunci : Pola Komunikasi, Prestasi Kerja Pegawai 
Abstract - The purpose of this research is to find out the magnitude of the effect of the application of organizational communication patterns on employee performance at the Jakarta Ministry of Education and Culture Communication Bureau The sample in this study were 50 employees from 102 populations. The data collection method used in this study is to use a questionnaire and processed with simple regression analysis. Test research instruments with validity and reliability tests. Hypothesis testing uses $t$ test (partial), and analysis of the coefficient of determination with the help of SPSS 21 for Windows software. Descriptive test results show that respondents who gave an assessment of communication indicators from the top down in the high category were 8 people (16\%), respondents who gave ratings in the medium category were 35 people (70\%), and respondents who gave ratings in the low category is 7 people (14\%). Respondents who gave an assessment of the communication pattern variables from the bottom up in the high category were 8 people (16\%), respondents who gave an assessment of the communication pattern variables from the bottom up in the medium category were 34 people (68\%), and respondents who gave assessment in the low category as many as 8 people (16\%). Respondents who gave an assessment of the variable indicators of horizontal communication patterns in the high category were 8 people (16\%), respondents who gave ratings in the medium category were 35 people (70\%), and respondents who gave ratings in the low category were 7 people (14\%). The majority of horizontal communication patterns are rated in the medium category (70\%). Based on the results of the coefficient test, the application of communication patterns contributes an effect of $48.9 \%$ to employee performance, while the rest of $100 \%-48.9 \%=51.1 \%$, is caused by other variables not examined. Based on the results of the t test above it can be seen that the Communication Pattern variable (X) has a $t_{\text {hitung }}$ of 6.779> $t_{\text {table }} 1.667$. This means that the communication pattern variable has a positive effect on employee performance, and a significant result is obtained that indicates the value of $0,000<0.05$, which means that there is a significant influence between communication patterns and employee performance. This shows that Ho was rejected and Ha was accepted, meaning that the variable implementation of communication patterns had a positive effect on employee performance at the Public Service Communication Bureau of the Ministry of Education and Culture in Jakarta. Thus, if the value of the communication pattern rises, employee performance will increase significantly.

Keywords: Communication Patterns, Employee Job Performance

\section{PENDAHULUAN}

\section{Latar Belakang}

Instansi dituntut menciptakan kinerja karyawan yang tinggi untuk pengembangan organisai. Organsiasi harus mampu membangun dan meningkatkan kinerja dalam lingkungannya. Keberhasilan orgnanisasi tersebut dipengaruhi oleh beberapa faktor, salah satu faktor penting adalah sumber daya manusia, karena sumber daya manusia merupakan pelaku dari keseluruhan tingkat perencanaan sampai dengan evaluasi yang mampu 
memanfaatkan sumber daya-sumber daya lainnya yang dimiliki oleh organisasi atau perusahaan.

Masalah SDM menjadi pusat perhatian pada suatu organisasi untuk dapat bertahan pada era globalisasi yang dimbingan dengan tingkat persaingan yang sangat ketat. Sumber daya manusia mempunyai peran utama dalam setiap kegiatan organisasi atau perusahaan. Hal ini menunjukkan bahwa manajemen sumber daya manusia merupakan kunci pokok yang harus diperhatikan.

Sumber daya manusia mempengaruhi kinerja dalam organisasi pemerintahan. Peran sumber daya manusia yang berkualitas dalam rangka kinerja pegawai merupakan faktor yang sangat penting. Kinerja pegawai tidak hanya ditentukan oleh pengguna sistem teknologi canggih, melainkan juga pendekatan pada perilaku dan sikap mental seorang pegawai untuk mencapai suatu prestasi atau kinerja pegawai. Salah satunya adalah melalui komunikasi.

Aktivitas komunikasi di perkantoran senantiasa disertai dengan tujuan yang ingin dicapai. sesama dalam kelompok dan masyarakat. Budaya komunikasi dalam konteks komunikasi organisasi harus dilihat dari berbagai sisi. Sisi pertama adalah komunikasi antara atasan kepada bawahan. Sisi kedua antara pegawai yang satu dengan pegawai yang lain. Sisi ketiga adalah antara pegawai kepada atasan. Masing-masing komunikasi tersebut mempunyai polanya masing-masing.

Komunikasi sangat penting dalam suatu organisasi, karena merupakan kelompok orang yang bekerja dan saling ketergantungan dalam pencapaian beberapa tujuan. Orang dapat bekerja dan saling ketergantungan melalui komunikasi. Komunikasi merupakan sarana melalui mana orang mengklarifikasi harapan mereka dan mengkoordinasi pekerjaan, yang memungkinkan mereka mencapai tujuan komunikasi dengna lebih efisien dan efektif.

Menurut Fayol dan Barnard dalam Thoha (2004:170) komunikasi merupakan salah satu pusat bahasan di dalam ilmu perilaku organisasi. Komunikasi yang efektif terjadi bila artian yang dimaksudkan oleh pengirim berita dan artian yang ditangkap oleh penerima berita itu sama dan satu. Peningkatan kinerja yang optimal dan efektif tersebut tidak mungkin terjadi jika tidak ada komunikasi yang efektif yang dilakukan oleh para pegawai, menurut Kohler dalam Muhammad (2011:1) komunikasi yang efektif adalah penting bagi semua organisasi. Oleh karena itu, para pimpinan organisasi dan para komunikator mereka. 
Pelaksanaan komunikasi yang tidak baik dapat mengganggu semua rencana, petunjuk, saran, instruksi, yang mengakibatkan pekerjaan menjadi kacau dan tujuan organisasi tidak tercapai. Komunikasi merupakan masalah penting karena banyaknya pelanggaran yang terjadi disebabkan oleh para pelaku tidak mengetahui bahwa mereka berada di luar jalur ketertiban. Oleh karena itu diperlukan adanya pelaksanaan dan penerapan komunikasi yang efektif yang dapat meningkatkan semangat dan kinerja pegawai, sehingga dengan adanya kinerja yang baik pula maka tujuan yang telah ditetapkan oleh perusahaan dapat lebih mudah dicapai dengan baik. Apabila terciptanya komunikasi yang baik, maka kinerja pegawai akan meningkat, sehingga tujuan perusahaan dengan hasil yang diharapkan akan dapat dicapai.

Menurut Wibowo (2014:241) bahwa komunikasi adalah merupakan proses penyampaian informasi dari satu pihak baik individu, kelompok atau organisasi sebagai sender kepada pihak lain sebagai receiver untuk memahami dan terbuka peluang memberikan respon balik kepada sender.

Sedemikian pentingnya komunikasi bagi kehidupan manusia sehingga komunikasi dipelajari dan dikembangkan guna meningkatkan kemampuan berkomunikasi dengan sesamanya dan dapat berkomunikasi secara efektif untuk mencapai tujuan. Pengguna komunikasi terus mengalami perkembangan seiring dengan perkembangan teknologi komunikasi. Dengan perkembangan teknologi komunikasi akan lebih memudahkan dengan pencapaian tujuan. Baik tujuan individu maupun tujuan perusahaan dan masyarakat.

Pola komunikasi merupakan sistem penyampaian pesan komunikasi dari komunikator kepada komunikan dengan maksud untuk merubah pendapat, sikap, maupun perilaku komunikasi. Sistem penyampaian didasarkan pada penggunaan sejumlah teoriteori komunikasi dalam menyampaikan pesan langsung ataupun melalui perantara media tertentu. Pesan komunikasi disampaikan melalui lambang (symbol) komunikasi dalam bahasa verbal maupun non-verbal serta media komunikasi lainnya seperti media teknologi informasi, media audio visual, surat kabar, majalah dll.

Pola komunikasi yang baik juga akan menghasilkan suatu kinerja yang baik. Kinerja sendiri merupakan hasil pekerjaan yang mempunyai hubungan kuat dengan tujuan strategi organisasi, kepuasan konsumen, dan memberikan kontribusi pada ekonomi. Kinerja seseorang merupakan hal yang bersifat individual, karena setiap karyawan mempunyai tingkat kemampuan yang berbeda-beda dalam mengerjakan tugasnya. Kinerja pada dasarnya mencakup sikap mental yang selalu mempunyai pandangan bahwa kehidupan 
hari ini harus lebih baik dari hari kemarin dan hari esok harus lebih baik dari hari ini. Sikap yang demikian akan mendorong seseorang untuk tidak cepat merasa puas, akan tetapi harus mengembangkan diri dan meningkatkan kemampuan kerja dengan cara selalu mencari perbaikan-perbaikan dan peningkatan.

Jadi, apabila pola komunikasi tidak berjalan sesuai aturannya, maka akan menjadi salah satu gangguan atau hambatan dalam mencapai kinerja karena pesan tidak tersampaikan dengan benar. Kinerja di sini tidak akan dapat meningkat tanpa adanya suatu komunikasi yang berjalan dengan baik sesuai dengan pola komunikasinya bila melihat adanya perbedaan bahasa dalam suatu perusahaan. Faktor pola komunikasi merupakan faktor yang berperan dalam menyatukan informasi dan saling bekerjasama dengan semua pihak yang terlibat langsung dalam organisasi, yang akan berdampak terhadap kinerja pegawai.

Kompleksitas tuntutan masyarakat terhadap pemerintah, untuk meningkatkan proses kerja dan memberikan perhatian serta pelayanan pada masyarakat luas. Di sisi lain pemerintah berupaya untuk meningkatkan komunikasi dalam organisasi secara profesional yang bersandar pada tuntutan good governance, yang pada gilirannya akan terwujud hubungan naturalisme positif antara pemerintah dalam hal ini Biro Komunikasi Layanan Masyarakat Kementerian Pendidikan dan Kebudayaan.

Dengan dikeluarkannya Peraturan Presiden Nomor 97 tahun 2014 tentang Penyelenggaraan Pelayanan Terpadu Satu Pintu, maka layanan pendidikan dan kebudayaan yang ditangani unit kerja masing-masing di lingkungan Kemdikbud dikelola secara terpadu satu pintu yang dikoordinasikan oleh Biro Komunikasi dan Layanan Masyarakat, Sekretariat Jenderal, Kemdikbud. Pada Kementerian Pendidikan dan Kebudayaan, Pelayanan Terpadu Satu Pintu dinamakan Unit Layanan Terpadu (ULT) yang mulai operasional pada tanggal 9 Maret 2015.

Bahri dalam Anhar (2010) bahwa pola komunikasi adalah suatu bentuk pola hubungan antara dua orang atau lebih dalam melakukan proses pengiriman dan penerimaan pesan dengan cara yang tepat dan efektif sehingga pesan yang akan ditujukan dapat dipahami.

Pola komunikasi organisasi memiliki pengaruh terhadap kinerja pegawai. Efektivitas pola komunikasi organisasi akan mendorong peningkatan kinerja pegawai. Hal ini sesuai dengan penelitian yang dilakukan oleh Dede (2012) yang menemukan bahwa dengan 
adanya pola komunikasi yang efektif akan dapat meningkatkan kinerja pegawai khususnya pada Dinas Pendidikan Provinsi Jawa Barat.

Kinerja merupakan perilaku nyata yang ditampilkan setiap orang sebagai prestasi kerja yang dihasilkan oleh pegawai sesuai dengan perannya dalam organisasi (Rivai dan Sagala, 2005:36), karena kinerja pegawai merupakan suatu hal yang penting dalam upaya organisasi untuk mencapai tujuannya. Kinerja adalah suatu tampilan keadaan secara utuh atas perusahaan selama periode waktu tertentu, merupakan hasil atau prestasi yang dipengaruhi oleh kegiatan operasional organisasi dalam memanfaatkan sumber-sumber yang dimiliki.

Kinerja pegawai pada suatu organisasi merupakan salah satu faktor yang menentukan perkembangan suatu organisasi. Jika kinerja pegawai baik maka tujuan organisasi akan tercapai dan sebaliknya apabila kinerja pegawai menurun mengakibatkan pekerjaan menjadi membosankan dan pekerjaan tidak selesai tepat pada waktunya. Setiap organisasi pasti dihadapkan pada berbagai masalah salah satunya masalah kinerja pegawai. Usaha dalam meningkatkan kinerja dan mengatasi masalah kinerja pegawai tentunya harus diperhatikan adalah kualitas sumber daya manusia yang baik sehingga akan mampu bekerja secara optimal.

Berdasarkan hasil wawancara dengan Bapak Asianto Sinambela selaku Kepala BKLM, fenomena yang terjadi selama ini bahwa kinerja pegawai khususnya pada Biro Komunikasi Layanan Masyarakat Kemendikbud masih rendah. Hal ini dapat dilihat dari adanya pegawai yang lambat dalam penyelesaian pekerjaan dan selain itu masih kurangnya disiplin pegawai dalam pengelolaan penerapan pola komunikasi organisasi.

Selain itu alasan pemilihan Biro Komunikasi Layanan Masyarakat Kementerian Pendidikan dan Kebudayaan adalah mengingat pembagian ruang lingkup yang terpisahpisah pada tempat dan kondisi yang berbeda. Pentingnya pola komunikasi organisasi untuk meningkatkan kinerja pegawai, karena kinerja pegawai merupakan hal yang penting bagi organisasi, sehingga ke depannya organisasi dapat mengambil tindakan yang tepat untuk menyikapi masalah flesibilitas ketentuan, sumber daya manusia dan lingkungan kerja setempat.

Dari latar belakang masalah yang telah dikemukakan maka penulis tertarik untuk membahas tema ini lebih jauh dengan memilih judul: "Pengaruh Pola Komunikasi Organisasi terhadap Kinerja Pegawai Pada Biro Komunikasi Layanan Masyarakat Kementerian Pendidikan dan Kebudayaan." 


\section{Identifikasi Masalah}

Berdasarkan pada latar belakang masalah dan teori di atas yang merujuk pada empirik dan normatif (data) maka dapat dikemukakan Identifikasi Masalah yang memiliki relevansi dengan penelitian ini yaitu:

1. Belum terpenuhi secara optimal penerapan pola komunikasi organisasi pada Pegawai Biro Komunikasi Layanan Masyarakat Kemendikbud.

2. Masih ada pegawai yang lambat untuk menyelesaikan pekerjaan.

3. Masih kurangnya komunikasi antara staf dan pimpinan, ditandai dengan tidak adanya pertemuan yang bersifat rutinitas antara staf dan pimpinan.

4. Masih kurangnya disiplin pegawai dalam pengelolaan penerapan pola komunikasi organisasi

\section{Perumusan Masalah}

Berdasarkan pada identifikasi masalah di atas maka dapat dikemukakan Perumusan Masalah sebagai berikut :

1. Apa penyebab Belum terpenuhi secara optimal penerapan pola komunikasi organisasi pada Pegawai Biro Komunikasi Layanan Masyarakat Kemendikbud?

2. Mengapa masih ada pegawai yang lambat untuk menyelesaikan pekerjaan?

3. Kenapa komunikasi antara staf dan pimpinan masih kurang, ditandai dengan tidak adanya pertemuan yang bersifat rutinitas antara staf dan pimpinan?

4. Apa penyebab masih kurangnya disiplin pegawai dalam pengelolaan penerapan pola komunikasi organisasi?

\section{LANDASAN TEORI}

\section{Pengertian Manajemen}

Pengaturan dilakukan melaui proses dan diaturnya berdasarkan urutan dari fungsi-fungsi manajemen itu (Perencanaan, Pengorganisasian, Pengarahan, Pengendalian). Jadi, manajemen itu merupakan suatu proses untuk mewujudkan tujuan yang diinginkan. Adapun unsur manajemen itu terdiri Men,Money, Method, Materials, Machine dan Market yang disingkat 6M. 
Dalam organisasi atau perusahaan, karena manajemen merupakan "alat" dan "wadah" (tempat) untuk mengatur $6 \mathrm{M}$ dan semua aktivitas proses perusahaan dalam mencapai tujuannya. Walaupun manajemen hanya merupakan alat saja, tetapi harus diatur sebaikbaiknya, karena jika manajemen ini tepat maka tujuan optimal dapat diwujudkan, pemborosan terhindari, dan semua potensi yang dimiliki akan lebih bermanfaat.

Untuk lebih jelasnya pengertian manajemen ini penulis mengutip beberapa definisi sebagai berikut:

Menurut G.R Terry yang dikutip oleh Kartono (2008:168) dalam bukunya "Pemimpin dan Kepemimpinan" manajemen adalah penyelenggaraan usaha penyusun dan pencapaian hasil yang diinginkan dengan menggunakan upaya-upaya kelompok, terdiri atas penggunaan bakatbakat dan sumber daya manusia.

Menurut Malayu S. P. Hasibuan (2012:1), dalam buku manajemen sumber daya manusia manajemen adalah ilmu dan seni mengatur proses pemanfaatan sumber daya manusia dan sumber lainnya secara efektif untuk mencapai suatu tujuan tertentu.

Menurut Panji Anoraga (2009:109) dalam bukunya manajemen bisnis, manajemen adalah proses yang khas terdiri dari tindakan-tindakan perencanaan, pengorganisasian, pelaksanaan, dan pengendalian yang masing-masing bidang tersebut digunakan baik ilmu pengetahuan maupun keahlian dan yang diikuti secara berurutan dalam rangka usaha mencapai tujuan organissi yang telah ditetapkan.

Berdasarkan pengertian tersebut dapat disimpulkan manajemen adalah suatu proses yang terdiri perencanaan, pengarahan, pengendalian, melaui pemanfaatan sumber daya manusia dan sumber daya lain secara efektif dan efisien untuk mencapai suatu tujuan tertentu.

1. Fungsi Manajemen

Dalam proses pelaksanaannya, manajemen mmpunyai tugas-tugas khusus yang harus dilaksanakan. Tugas-tugas itulah yang biasa disebut sebagai fungsi-fungsi manajemen.

Menurut George R. Terry terdapat 4 fungsi manajemen, yang dalam dunia manajemen dikenal sebagai POAC: Yaitu planning (perencanaan), organizing (pengorganisasian), actuating (pengarahan) dan controlling (pengendalian).

a. Planning (Perencanaan)

Perencanaan ialah kegiatan yang akan dilakukan di masa yang akan datang untuk mencapai tujuan. Empat tujuan yang penting dari perencanaan :

1) Mengurangi atau mengimbangi ketidakpasstian dan perubahan yang akan datang.

2) Memusaatkan perhatian kepada sasaran 
3) Menjamin atau mendapatkan proses pencapaian tujuan terlaksana secara efisien dan efektif.

4) Memudahkan pengendalian.

Jadi perencanaan dalam manajemen kesiswaaan perlu dilakukan, yaitu sebagai patokan dalam melaksanakan kegiatan.

b. Organizing (Pengorganisasian)

Istilah organisasi mempunyai dua pengertian umum. Pertama, organisasi diartikan sebagai suatu lembaga atau kelompok fungsional. misalnya, sebuah perusahaan, sebuah sekolah, sebuah perkumpulan, badan-badan pemerintahan. Kedua, merunjuk pada proses pengorganisasian yatu bagaimana pekerjaan diatur dan dialokasikan diantara para anggota, sehingga tujuan organisasi itu dapat tercapai secara efektif. Sedangkan organisasi itu sendiri diartikan sebagai perkumpulan orang dengan sistem kerjasama untuk mencapai tujuan bersama. Dalam sistem kerjasama secara jelas diatur siap menjalankan apa, siapa pertanggung jawab atas siapa, arus komunikasi, dan memfokuskan sumber daya pada tujuan.

Pengorganisasian sebagai proses membagi kerja ke dalam tugas-tugas yang lebih kecil, membebankan tugas-tugas itu kepada orang yang sesuai dengan kemampuannya, dan mengalokasikan sember daya, serta mengkoordinasikannya dalam rangka efektivitas pencapaian tujuan organisasi.

Jadi setelah melaksanakan perencanaan langkah selanjutnya adalah pengorganisasian, dalam hal ini harus jelas siapa yang menjalankan dan apa yang dijalankan, agar semuanya berjalan dengan lancar.

c. Actuating (penggerakan/pengarahan)

Penggerakan/pengarahan adalah fungsi manajemen yang terpenting dan paling dominan dalam proses manajemen. Fungsi ini baru dapat diterapkan setelah rencana, organisasi, dan karyawan ada. Jika fungsi ini diterapkan maka proses manajemen dalam merealisasi tujuan dimulai. Penerapan fungsi ini sangat sulit, rumit, dan kompleks, karena karyawan-karyawan tidak dapat dikuasai sepenuhnya. Hal ini disebabkan karyawan adalah makhluk hidup yang punya pikiran, perasaan, harga diri, cita-cita, dan lainnya.

Oleh karena itu pengarahan perlu dijalankan dengan sebaik-baiknya, dan perlu kerjasama yang baik pula di antara semua pihak baik dari atasan maupun bawahan. 


\section{d. Controlling (pengendalian/pengawasan)}

Pengendalian/pengawasan ini berkaitan erat sekali dengan fungsi perencanaan dari kedua fungsi ini merupakan hal yang saling mengisi, karena:

1) Pengendalian harus terlebih dahulu direncanakan

2) Pengendalian baru dapat dilakukan jika ada rencana

3) Pelaksanaan rencana akan baik, jika pengendalian dilakukan dengan baik

4) Tujuan baru dapat diketahui tercapai dengan baik atau tidak setelah pengendalian atau penilaian dilakukan.

Maka inti dari pengawasan adalah untuk mengatur pekerjaan yang direncanakan dan memastikan bahwa pelaksanaan pekerjaan tersebut berlangsung sesuai rencana atau tidak. Kalau tidak sesuai dengan rencana maka perlu adanya perbaikan..

\section{Pengertian Manajemen Sumber Daya Manusia}

Sumber Daya Manusia merupakan komponen dari perusahaan yang mempunyai arti yang sangat penting sumber daya manusia menjadi sumber penentu dari perencanaan tujuan suatu perusahaan, karena fungsinya sebagai inti dari kegiatan perusahaan. Tanpa adanya sumber daya manusia maka kegiatan perusahaan tidak akan berjalan sebagaimana mestinya meskipun pada saat ini otomatisasi telah memasuki setiap perusahaan, tetapi apabila pelaku dan pelaksana mesin tersebut yaitu manusia, tidak memberikan peranan yang diharapkan maka otomatisasi itu akan menjadi sia-sia.

Untuk lebih memperjelas pengertian dari manajemen sumber daya manusia, berikut ini penulis mengutip beberapa definisi yang dikemukakan oleh beberapa ahli:

Menurut Rivai (2008:10) manajemen sumber daya manusia adalah salah satu bidang dari manajemen umum yang meliputi segi-segi perencanaan, pengorganisasian, pelaksanaan dan pengendalian.

Menurut Mangkunegara (2007:2) manajemen sumber daya manusia adalah suatu pengelolaan dengan pendayagunaan sumber daya yang ada pada inividu pegawai.

Menurut Gary Dessler (2010:4) manajemen sumber daya manusia sebagai kebijakan dan latihan untuk memenuhi kebutuhan karyawan atau aspek-aspek yang terdapat dalam sumber daya manusia seperti posisi manajemen, pengadaan karyawan atau rekrutmen, penyaringan, pelatihan, kompensasi, dan penilaian prestasi kerja karyawan. 
Berdasarkan pengertian tersebut dapat disimpulkan Manajemen Sumber Daya Manusia mengatur semua tenaga kerja secara efektif dan efisien dengan mengembangkan kemampuan yang mereka miliki dalam mewujudkan tujuan perusahaan, karyawan, dan masyarakat. Dengan memiliki tujuan tertentu maka tenaga kerja akan termotivasi untuk bekerja sebaik mungkin.

\section{METODOLOGI PENELITIAN}

Metodologi penelitian adalah suatu cara untuk mendapatkan data-data guna memperoleh pengetahuan yang dapat dikembangkan untuk memecahkan masalah tertentu.

Metodologi penelitian menurut (Sugiyono, 2011:2) adalah cara ilmiah (rasional, empiris, dan sistematis) untuk mendapatkan data dengan tujuan dan kegunaan tertentu. Rasional yang berarti kegiatan penelitian tersebut dilakukan dalam penelitian tersebut dapat diamati oleh panca indera manusia. Sistematis yang berarti proses dalam penelitian tersebut menggunakan langkah-langkah yang bersifat logis.

\section{Ruang Lingkup Penelitian}

Penelitian yang dilakukan penulis menggunakan metode penelitian kuantitatif. Metode kuantitatif atau sering disebut juga metode tradisional adalah data yang dihasilkan dari penelitian dengan metode ini berupa angka-angka dan analisisnya mengguakan statistik. Seperti yang dikemukakan oleh (Sugiyono, 2011:10) metode kuantitatif menurut sifat realistisnya adalah dapat diklasifikasikan, konkrit dan terukur. Menurut hubungan variabelnya ditambahkan lagi oleh (Sugiyono, 2011:11) bahwa metode kuantitatif dalam hubungan variabel terhadap objek yang diteliti bersifat sebab akibatnya (kausal) sehingga dalam penelitan terdiri variabel independen dan variabel dependen.

1. Tempat Penelitian

Penelitian ini dilaksanakan pada Biro Komunikasi Layanan Masyarakat Kemdikbud Jakarta

yang beralamat di Komplek Kementerian Pendidikan dan Kebudayaan Jln. Jenderal

Sudirman Gedung C Lantai 4 Senayan Jakarta Pusat 10270.

2. Waktu Penelitian

Kegiatan penelitian ini dilakukan pada bulan September 2016 sampai dengan Februari 2017. 


\section{HASIL DAN PEMBAHASAN}

\section{Gambaran Umum Perusahaan}

Biro Komunikasi Layanan Masyarakat Kemdikgud Berdiri sejak tahun 2019 yang memiliki memilik unit kerja melayani masyarakat yang datang langsung digerai informasi Media di bawah naungan Pusat Informasi dan Humas (PIH)

Sejak diberlakukanya UU No. 14 Tahun 2018, tanggal 1 Mei 2010 tentang Keterbukaan Informasi Publik, layanan masyarakat yang meminta informasi dan menyampaikan claim di Kemdikbud dialyani melalui satu pintu yaitu Pusat Informasi dan Humas. Sementara itu, layanan pendidikan lainnya seperti tunjangan sertifikasi guru, dapodik, NRG, NISN, bansos, dll masih ditangani oleh unit kerja dilingkungan Kemdikbud.

Dengan terbitkan Peraturan Presiden No. 97 tahun 2014 tentang Penyelenggaraan Pelayanan Terpadu Satu Pintu, maka layanan pendidikan dan kebudayaan yang ditangani unit kerja dilingkungan Kemdikbud dan dikelola secara terpadu satu pintu yang dikoordinasikan oleh Biro KLM, Sekretariat Jenderal, Kemdikbud.

Pada Tanggal 9 Maret 2015 Kemdikbud memberlakukan Unit Pelayanan Terpadu (ULT)

\section{Tugas dan Fungsi}

Menurut Permendikbud No. 11 Tahun 2015, Tupoksi Biro KLM adalah:

a. Mengadakan Koordinasi dan pengelolaan informasi, publikasi, dan hubungan antar lembaga;

b. Pengumpulan, pengolahan, dan penyajian data dan informasi di bidang pendidikan dan kebudayaan;

c. Pelaksanaan publikasi di bidang pendidikan dan kebudayaan;

d. Pelaksanaan hubungan dengan lembaga negara, lembaga pemerintah, lembaga masyarakat, dan media;

e. Pengelolaan perpustakaan Kementerian Pendidikan dan Kebudayaan;

f. Pemberian layanan informasi di bidang pendidikan dan kebudayaan;

g. Koordinasi dan pelaksanaan layanan masyarakat di bidang pendidikan dan kebudayaan;

h. Evaluasi dan penyusunan laporan pengelolaan informasi, publikasi, hubungan antarlembaga, dan layanan masyarakat di bidang pendidikan dan kebudayaan; dan

i. Pelaksanaan urusan ketatausahaan dan kerumahtanggaan Biro. 


\section{Gambar Struktur Organisasi}

\section{Gambar 4.1}

Struktur Organisasi

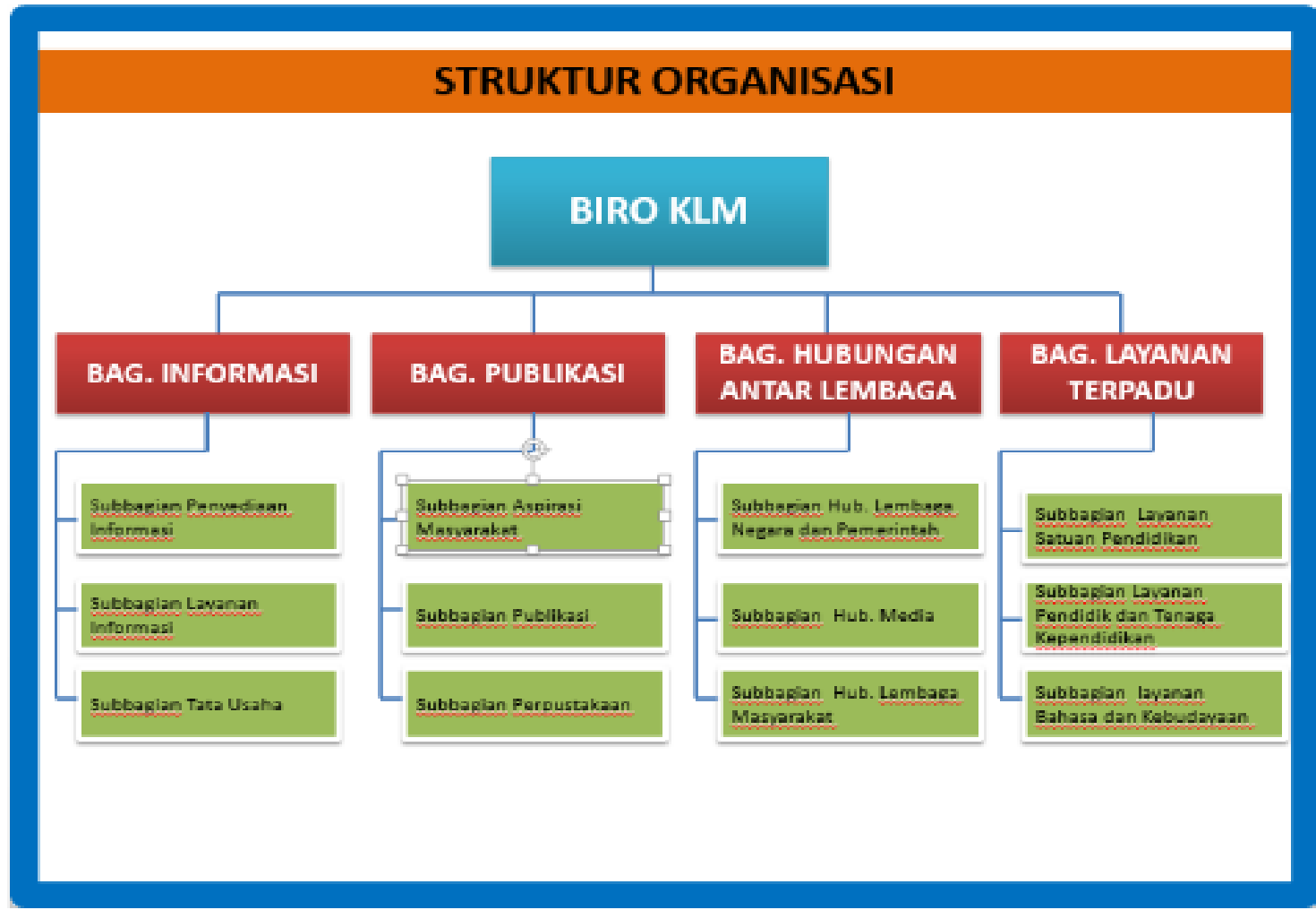

\section{Visi}

Terwujudnya Layanan Prima Informasi dan Kehumasan Pendidikan dan Kebudayaan yang Berkualitas.

\section{Misi}

1. Terselenggaranya layanan informasi dan Kehumasan yang berkualitas berbasis IT.

2. Meningkatnya indeks kepuasan pemangku kepentingan Kemendikbud.

\section{Gambaran Umum Kegiatan}

1. Publikasi Kebijakan Kemdikbud Melalui Media Cetak, Elektronik dan Online (Iklan layanan masyarakat, talkshow, Advetorial cetak \& online);

2. Pengelolaan layanan pengaduan dan layanan terpadu;

3. Penyusunan dan pengolahan data informasi pendidikan dan kebudayaan;

4. Koordinasi dan fasilitasi hubungan lembaga negara, pemerintah, media dan lembaga 
masyarakat;

5. Pengelolaan Media Sosial dan Portal;

6. Liputan dan Pendampingan Media;

7. Pameran Pendidikan dan Kebudayaan;

8. Survey kepuasan pemangku kepentingan;

9. Pemberian apresiasi kepada pemerhati pendidikan dan kebudayaan;

10. Analisa berita media masa;

11. Sosialisasi kebijakan pendidikan dan kebudayaan;

12. Pembinaan dan Pengelolaan layanan perpustakaan Kemendikbud;

13. Layanan ketatausahaan Biro

\section{Peran BKLM dalam Komunikasi Masyarakat}

1. Mengkomunikasikan dan menginformasikan Kebijakan dan program kegiatan kepada masyarakat

2. Menampung aspirasi masyarakat saran dan pengaduan

3. Memberikan penjelasan pertanyaan dari masyarakat.

4. Menjadi juru bicara

5. Mengcounter berita negatif dan memberikan apresiasi berita positif

6. Memberikan citra positif terhadap institusi/lembaga

7. Membangun hubungan yang baik dengan media

8. Meningkatkan koordinasi dalam penyebarluasan informasi mengenai kebijakan pemerintah;

9. Membangun citra dan reputasi positif.

10. Menciptakan komunikasi timbal balik antara instansi pemerintah dan masyarakat yang terencana untuk menciptakan saling pengertian dalam mencapai tujuan, demi memperoleh manfaat bersama.

\section{Peran BKLM dalam Pelayanan Publik}

1. Tuntutan aspirasi masyarakat terhadap Kegiatan pelayanan publik yaitu pelayanan yang bermutu

2. Masyarakat menghendaki pelayanan publik yang cepat, mudah, dan murah

3. Keterlibatan masyarakat dalam penyusunan standar pelayanan sehingga adanya 
pemahaman dan persepsi yang sama bagi pelaksana dan masyarkat

4. Diperlukan standar pelayanan di tiap unit pelayanan sebagai jaminan dan kepastian kegiatan pelayanan.

5. Pelayanan publik di Kemdikbud melalui satu pintu yaitu di Unit Layanan Masyarakat, Gedung C Lantai Dasar Kemdikbud.

6. ULT dilaksanakan sejak 9 Maret 2015 yang dikoordinasikan oleh BKLM, sarana dan Prasarana oleh Biro Umum, dan jaringn oleh Pustekom.

7. Pelayanan di ULT meliputi pelayanan pengurusan, perizinan, permintaan informsi, dn penangan pengaduan.

8. Pelayanan di ULT dengan tujuan agar masyarakat yang mengurus tentang pendidikan dan kebudayaan dapat ditangani pada satu tempat dan memberikan kepastian dalam waktu penyelesian

9. Semua jenis layanan puiblik di kemdikbud harus dibuat SOP dan SP.

10. Melalui ULT ini masyarakat dapat menyelesaiakan berbagai urusan dikbud pada satu pintu

\section{Dasar Hukum Layanan Publik}

1. UU. nomor 14 tahun 2008 tentang Keterbukaan informasi pubik

2. UU. nomor 25 tahun 2009 tentang Layanan Publik.

3. Perpres nomor 97 tahun 2014 tetang penyelanggaraan pelayanan terpadu satu pintu

4. Instruksi Mendikbud tanggal 8 Januari 2015 Pelayanan Masyarakat di Kemdikbud melalui satu pintu pada unit layanan terpadu.

5. Permendikbud Nomor 11 Tahun 2015 Tentang Organisasis dan Tata Laksana di Lingkungan Kemdikbud.

\section{Tujuan Unit Layanan Terpadu}

1. Memberikan perlindungan dan kepastian hukum kepada masyarakat;

2. Memperpendek proses pelayanan;

3. Mewujudkan proses pelayanan yang cepat, mudah, murah, transparan, pasti, dan terjangkau; dan

4. Mendekatkan dan memberikan pelayanan yang lebih luas kepada masyarakat. 


\section{PENUTUP}

\section{Kesimpulan}

Dari hasil analisis dan pembahasan mengenai pengaruh pola komunikasi organisasi terhadap kinerja pegawai pada Biro Komunikasi Layanan Masyarakat Kemdikbud Jakarta, maka dapat ditarik beberapa kesimpulan berikut :

1. Berdasarkan hasil analisis ada pengaruh positif gaya komunikasi vertikal, Harisontal dan Diagonal terahadap prestasi kerja Pegawai pada Biro Komunikasi Layanan Masyarakat Kemdikbud . Jadi dapat dikatakan bahwa semakin baik komunikasi organisasi yang dilakukan oleh pegawai maka tingkat kinerja yang dimiliki pegawai akan menjadi lebih baik. Sebaliknya, pegawai yang kurang memiliki kemampuan dalam berkomunikasi pada Biro Komunikasi Layanan Masyarakat Kementerian Pendidikan dan Kebudayaan Jakarta maka tingkat kinerja pegawai juga akan rendah.

2. Hasil Deskriptif menunjukkan bahwa responden yang memberikan penilaian terhadap variabel kinerja pegawai dalam kategori tinggi yaitu (0\%), responden yang memberikan penilaian dalam kategori sedang yaitu sebanyak 9 orang (18\%), dan responden yang memberikan penilaian dalam kategori rendah yaitu sebanyak 41 orang (82\%). Kinerja pegawai mayoritas dinilai dalam kategori rendah $(82 \%)$.

3. Dari Hasil uji regresi diperoleh hasil bahwa variabel pola komunikasi organisasi berpengaruh terhadap prestasi kerja pegawai Biro Komunikasi dan Layanan Masyarakat Kemdikbud, yang dibuktikan dengan nilai beta, serta nilai thitung yang lebih besar dibandingkan dengan nilai ttabel, selain itu memiliki nilai sig lebih kecil.

\section{Saran}

Dari hasil analisis dan kesimpulan dapat disarankan :

1. Agar Biro Komunikasi dan Layanan Masyarakat Kemdikbud Jakarta tetap menjalankan komunikasi yang baik dan lancar antara pegawai dengan pimpinan, serta tetap menjalin komunikasi dengan atasan dengan bawahan, bawahan dengan atasan dan rekan kerja

2. Agar pimpinan senantiasa memberikan kesempatan kepada setiap pegawai agar menerapkan pola komunikasi vertikal ke atas, komunikasi vertikal ke bawah, komunikasi horizontal dan komunikasi silang.

3. Agar peneliti berikutnya kiranya menambah variabel atau indikator lain agar lebih memahami variabel-variabel atau indikator-indikator yang mempengaruhi kinerja pegawai, 
antara lain kemampuan kerja, komunikasi, komitmen, semangat kerja, karakteristik pekerjaan dan lain-lain.

\section{DAFTAR PUSTAKA}

Bernardin, John H., dan Russel, Joyce E. A., Human Resources Managment: An Experiental Approach, (Jakarta: Gramedia Pustaka, 2008).

Cangara, Hafied, Pengantar Ilmu Komunikasi, Penerbit: Radja Grafindo Persada, Jakarta, 2005.

Bahri, Syaiful, D., Pola Komunikasi Orang Tua dan Anak dalam Keluarga. Penerbit: Reneka Cipta, Jakarta, 2004

Onong Uchjana, E. Ilmu Teori dan Filsafat Komunikasi. Penerbi: Remaja Rosdakarya. Bandung, 2009.

Hakim, Rahmat Budi, Manajemen dan Evaluasi Kinerja Karyawan, edisi pertama, cetakan pertama, Penerbit: Aswaja Pressindo, Jakarta, 2014.

Husain, Umar, Riset Pemasaran, Dan Perilaku Konsumen, cetakan ketiga, Gramedia Pustaka Utama, Jakarta, 2003.

Engkus, K. Etnografi Komunikasi: Suatu Pengantar dan Contoh Penelitiannya, Penerbit: Widya Padjajaran, Bandung, 2008.

Marihot, Manullang, Manajemen Personalia, cetakan kedua, Penerbit: Gadjah Mada University Press, Yogyakarta, 2004.

Mulyana, Deddy, Ilmu Komunikasi Suatu Pengantar, Penerbit: Remaja Rosdakarya, Bandung, 2008.

Pace, R. Wayne dan Faules, Don F, Komunikasi Organisasi, Penerbit: PT. Remaja Rosdakarya, Bandung, 2005.

Rakhmat, J., Metode Penelitian Komunikasi. Penerbit: Remaja Rosdakarya, Bandung, 2008.

Rivai, Veithzal dan Jauvani Sagala, Manajemen Sumber Daya Manusia untuk Perusahaan Dari Teori ke Praktik, Penerbit: PT. Raja Grafindo Persada, Jakarta, 2005.

Robbins, S dan Coulter, M, Manajemen, edisi kedelapan, Penerbit: PT. Indeks, Jakarta, 2007.

Romli, Komsahrial, Komunikasi Organisasi Lengkap, Penerbit: Grasindo, Jakarta, 2011.

Sedarmayanti, Manajemen Sumber Daya Manusia, cetakan kedua, Penerbit: Mandar Maju, Bandung, 2008. 
Sembiring Masana, Budaya Kinerja Organisasi, (Perspektif Organisasi Pemerintah), Penerbit: Fokus Media, Bandung, 2012.

Sinambella Poltak Lijan, Kinerja Pegawai Teori Pengukuran dan Implikasi, edisi pertama, cetakan pertama, Penerbit: Graha Ilmu, Jakarta, 2012.

Sugiono, Statistik Untuk Penelitian, cetakan kesembilanbelas, Penerbit: Alfabeta, Bandung, 2010.

Sugiono, Metode Penelitian Kuantitatif, Kualitatif, R\&D”, CV. Alfabeta, Bandung, 2009

Wibowo, Perilaku Dalam Organisasi, edisi pertama, cetakan kedua, Penerbit: RadjaGrafindo Persada, Jakarta, 2014.

Wijayanto, D., Pengantar Manajemen, Penerbit: Gramedia Pustaka Utama, Jakarta, 2012. 